\title{
A Principal-Agent Theory Perspective on PPP Risk Allocation
}

\author{
Asheem Shrestha ${ }^{1} \mathbb{D}$, Jolanta Tamošaitienè ${ }^{2, *} \mathbb{D}$, Igor Martek ${ }^{1}$, M Reza Hosseini ${ }^{1} \mathbb{D}$ and \\ David J Edwards ${ }^{3}$ \\ 1 School of Architecture and Built Environment, Deakin University, 1 Gheringhap Street, \\ Geelong, VIC 3220, Australia; asheem.shrestha@deakin.edu.au (A.S.); igormartek@yahoo.com (I.M.); \\ reza.hosseini@deakin.edu.au (M.R.H.) \\ 2 Faculty of Civil Engineering, Vilnius Gediminas Technical University, Saulètekio al. 11, \\ LT-10223 Vilnius, Lithuania \\ 3 Faculty of Computing, Engineering and the Built Environment, Birmingham City University City Centre \\ Campus, Millennium Point, Birmingham B47XG, UK; david.edwards@bcu.ac.uk \\ * Correspondence: jolanta.tamosaitiene@vgtu.lt; Tel.: +370-5-274-5231
}

Received: 10 October 2019; Accepted: 13 November 2019; Published: 16 November 2019

\begin{abstract}
This study proposes a framework for the allocation of risk in public private partnerships (PPP) projects. Its contribution lies in the recognition and incorporation of risks introduced by project stakeholders, and as articulated by the principal-agent theory (PAT). The framework assesses risks and routes these risks to those parties best equipped to mitigate their impact on the project. This allocation of risk is facilitated by a thirteen-step process. The practical benefit of this study lies in outlining a clear, systematic method for allocating risk efficiently to both the government and private enterprise parties of the project. In so doing, risk mitigation can be expected to improve project performance, optimize stakeholder goals, and enhance sustainability objectives, including improved operational life-cycle efficiency and elevated social and community benefits.
\end{abstract}

Keywords: risk allocation; public private partnerships; PPP; principal-agent theory

\section{Introduction}

Long term collaboration between the public and the private sector is essential for sustainable economic growth. It brings better efficiency and sustainability in the delivery of public services by fostering innovation and private sector financing [1]. However, according to the World Bank, there is a significant gap between available investment and the investment required for the provision of services [2]. Public private partnerships (PPPs) are an effective means to fund the growing demand for infrastructure and services [3] in an environment of limited public funds [4,5]. Yet, while PPPs are now widely utilized and accepted as a mainstream procurement model, management of their associated risks remains fraught, with sometime disastrous consequences [6]. The complexity of PPPs, along with multi-faceted stakeholder involvement and interests, combined with characteristically lengthy maturity periods, together greatly amplify project risk [7-9]. As a result, management of project risk is now regarded as a priority in PPP project delivery [7,10,11].

There are of course any variety of methods for parceling out risks, along with the associated responsibility of managing those risks, to the various stakeholders to a project [12]. Mostly, however, this process is linked to (financial) compensation in exchange for taking risk on [12]. The underlying assumption is that risks will be 'auctioned off' to whoever can best manage them and consequently price them lower. Moreover, in this scenario, a project benefits only from risks being fully allocated and managed, regardless of who it is that takes on the risk $[13,14]$. The insight provided by principal-agent 
theory (PAT) is that stakeholders to a project-the ones potentially bearing project risk-may not always, or in every way, share the projects goals. Through the lens of PAT, there exists, therefore, a disequilibrium between parties to a project in commitment to the project's success. In allocating risk, the problem compounds from merely finding who will 'buy' the responsibility for managing risk most cheaply, to one of finding who will ensure risk is mitigated dutifully to the best interests of the project and not to the self-interest of the risk-holding stakeholder [15]. PPP projects, as large-sized capital investments, are acutely vulnerable to multi-tier principal-agent complications arising from an intricate network of multiple government departments in which the private sector as the agent is enmeshed [15,16].

The conflict of interest between stakeholders to a project and the success of the project itself, has been extensively discussed in the PAT literature. PPPs, in particular, represent fertile ground for such an examination since the potential conflicts between project and stakeholders-government agencies and private companies-are especially pernicious, given the large investment outlays involved and the extensively lengthy payback periods. Examination of this conflict, however, in PPP projects has not been widely considered [17]. While private enterprise, as builders and concessionaires of the project, and government, as procurers and custodians representing the interest of the community, will together aim to deliver a successful outcome, each party bears additional incentive to extract gains from the other as well as from the project itself. Specifically, each side looks not only to the project to maximize profit, but seeks out ways to extract gains from the other side. As an example, there may be an informational asymmetry regarding the potential severity of a particular project risk. One side may price the risk cheaply, while the other side, knowing the risk has been underestimated may let it go to them, even though they were better able to manage the risk [16]. That is, they save money by not sharing all they know, while endangering the project outcome $[13,16,17]$. So in essence, risk management within the context of PPP projects may have been largely overlooked $[3,18]$. Thus, the application of PAT in risk allocation is both timely and relevant.

While existing studies have highlighted agency problems $[13,14,19]$, and while risk allocation frameworks do exist [20-22], frameworks that focus directly on solving agency problems via efficient risk allocation are rare. Exceptions, however, include recent work by Shrestha et al. [17] that use the PAT approach to analyze risk transfer in PPPs. Drawing from this study, this paper develops a framework that can be used by parties to a PPP project to negotiate risk allocation at the ex-ante stage by examining key risk allocation parameters from the risk management literature and subsequently, analyzing these parameters using a PAT approach.

The significance of this research has both theoretical and practical implications. From the theoretical perspective, this framework determines the parameters that are essential in the efficient allocation and transfer of risks in project management endeavors, and thus fills theoretical gaps in existing knowledge. From the practical perspective, the developed framework can assist PPP partners in explaining risks applicable to PPP contracts, and provides a stepping-stone that informs all parties involved in PPPs in the risk negotiation process.

\section{Efficient Risk Allocation in PPPs}

PPP has been defined as occurring: "where public sector bodies enter into long-term contractual agreements with private sector entities for the construction or management of public sector infrastructure facilities by the private sector entity, or the provision of services (using infrastructure facilities) by the private sector entity to the community on behalf of a public sector entity" [7]. The rationale behind PPPs, and similar applications of private participation in the procurement of public services, is the view that the private sector, with its superior technical and managerial abilities, is better placed to deliver a competitive, high-performing, and cheaper, product than is the government [6]. Moreover, since PPPs involve both the initial building followed by the operation of the public service project, this procurement method incentivizes the private sector to ensure efficiency over the whole project lifecycle. Specifically, the builder will avoid cost-cutting short-cuts in the 
building stage that would result in exacerbated costs to the operational stage, since they would only be cheating themselves $[23,24]$. In fact, studies show that the construction projects procured under PPP contracts outperform conventional projects across the board, including in terms of time, quality, and budget $[25,26]$. Even so, a persistent problem remains, which is the sub-optimal allocation of risks, and it is this factor that remains the primary cause of PPP failures [12,27].

Thus, the efficient allocation of project risk stands out as a key challenge in ensuring PPP project 'success' [3,5,27-29]. What 'success' means, however, needs careful scrutiny, since the parties to the project-the private firm and government-while sharing the goal of delivering an efficient working project, will nevertheless differ in other objectives [30,31]. Since, PPPs bring parties together as partners, it is important that the mechanism for allocating risks is consistent in incentivizing participants towards achieving the projects common goal, while also allowing each party to realize their additional objectives [31]. At the extreme, government will seek to transfer all project risk to the private party, while the private party will seek to maximize premiums charged for taking on those risks [32]. The interests of the project, however, may be better served by the government retaining certain risks-those it can better control (such as number of users), while project costs can be expected to go down where government is better informed about the nature of risks involved, calling out excessive risk premiums the private sector may be hoping to extract [33].

Though risk matrices are already provided in the tender documents, and while relevant guidelines and policy provide recommendations on how risks should be allocated, risk allocation negotiations still occur between the parties before the contracts are finalized. As each project is different and may involve different risks, the flexibility in the PPP contracts (for example, inclusion of power to order variations) are also negotiated.

In practice, two anomalies stand out. PPP contracts tend to assign risks to the party least able to refuse them, and thus often those risks are left to the party least able to manage them [22]. This misallocation of risk remains a significant impediment to PPP success [34]. Awareness of this problem has given rise to a series of studies examining efficient risk allocation strategies. Ameyaw and Chan [35] identify thirteen models for allocating risks in PPPs. Essentially, these risk allocation models seek a compromise in the degrees of success that both the government and the private sector parties can achieve from PPP projects. In this study, we draw from contract theory to define 'efficient risk allocation' as the assigning of risks to parties of their basis of their ability to best manage the risk [12].

The definition of risks vary in literature. A notable work on the topic by March and Shapira [36] highlight two main perspectives on the definition of risk: the economic perspective and the managerial perspective. According to Bahli and Riverd [37], the economic perspective views risk as the variance of a probability distribution of possible gains and losses associated with a given alternative. From a managerial perspective, risk is defined as uncertainty that is associated with negative outcomes. The latter perspective is generally used to define risk in the project management literature. As this study examines risk from an agency problem perspective, we too will take a defensive approach to apply a management perspective to examine risk.

Furthermore, we examine the allocation of exogenous risks and endogenous risks. Li et al. [38] define exogenous risks as those external to the project, i.e., risk events occurring beyond the system boundaries of a project but whose consequences cross the project boundary to impact upon the project and its outcomes; and endogenous risk is defined as risk events and their consequences occurring within the system boundaries of the project. This classification precedent is widely accepted in this area of research, having been used by several other researchers examining risk allocation in PPP projects $[8,12]$.

\section{Application of the Principal Agent Theory (PAT)}

PAT is a mature body of work, which explores the conflicts of interests arising between various project stakeholders, charged with its procurement, development and management, and with delivering the stated objectives of the project itself [39]. While both project contractor and client may partner to 
deliver a project outcome, the collaboration may not be an equal one. One side may be more powerful than the other; in terms of knowledge, skills, influence or finances [40]. Moreover, they may retain competing interests, and may even take on parasitic roles-syphoning off benefits from the project, while allowing the project to survive healthily enough to ensure the on-going flow of those benefits. Thus, the agency problem arises when these competing interests appear. A prominent feature of this problem is the mal-apportioning of risk to the party least able to resist the risk, leaving the project at risk of sub-optimal performance.

Principal agent conflicts were first identified by Coase [41], who asked the fundamental question of why it is that firms exist. Alchian and Demsetz [42] further developed the concept, looking into property rights and the theory of the firm. In Demsetz's [43] assessment, neoclassical economics ignored the problems relating to the structure of property rights and contractual arrangements where it was assumed that ownership and management resided in a single person. Developments in the theory of the firm had two themes:

- "a tendency for individuals to pursue their own interest in ways that conflict with the goals of the team" and,

- " an adjustment of ownership structures and contracts so as to reduce the degree to which team goals are compromised by this tendency" [43].

PAT centers on two problems: 'adverse selection' and 'moral hazard' [44]. Firstly, adverse selection occurs when the principal selects an agent who may not be the most appropriate. In this situation, the principal will not fully know the ability of the agent; either at time of selection (ex-ante) or while under contract (ex-post) [45]. Secondly, a moral hazard arises when an agent acts in self-interest to meet their own goals, doing so at the expense of the principal [46]. Principals cannot readily identify manifestations of moral hazard, due to a lack of accessible information (they cannot monitor the day-to-day activities of their agent.) Moral hazards are exemplified by private companies lowering product quality to reduce production costs, or in lobbying government to grant higher subsidies. PAT aims at resolving these issues [45].

A convincing case may be made for applying transaction cost economics (TCE) theory in PPP risk allocation due to the strategic and opportunistic behaviors involved in PPPs. Incomplete PPP contracts in lengthy and uncertain environments generally require renegotiations which can result in high transaction costs. While transaction cost theory and PAT essentially focus on similar issues, using PAT as a lens is justified as it focuses more on the relationship between the principal and the agent, whereas transaction cost theory focuses on individual transitions. The literature suggests serious issues relating to the trust between the government and the private sector in PPPs [47] and focus on the relationship aspect is a priority, given its capacity to reduce risks via efficient allocation of responsibilities [48]. PAT focuses more on incentive alignment and monitoring to reduce information asymmetry while TCE focuses more on ex post governance mechanisms to solve the issues of bounded rationality and asset specificity. Moreover, the governance problem in TCE is not to protect the rights of the end-users, but to accomplish effective transactions. On the other hand, PAT examines the problem of private sector self-interest that may compromise social benefits. The PAT approach is thus more relevant to PPPs.

Governments use PPPs as a low-cost vehicle to promote economic development and social welfare maximization [3]. Private firms, however, will not share these goals as a priority. Rather, they are motivated by profit and consequently can be expected to promote efficiency over effectiveness. Typically, they aim at reducing expenses, often by cutting costs, which in turn can compromise outcomes [45]. The dilemma of PPP project procurement is that while private participation offsets procurer cost burdens, it also places the private partner in significant control of the project, inviting actions that siphon off benefits to the project contractor at the expense of the procurer, whose interests they are supposed to serve [14].

Strategies for safeguarding public interest in PPP contracts is important for governments as public interest is treated as something that promotes social welfare and is considered synonymous with 
public policy [49]. For the government, a successful delivery of PPP should demonstrate value for money (VfM) benefits. Though we assume that the government principals act in the public interest, we cannot discard the fact that they also have their own self-interest. An important agenda for the government principal is also to be re-elected. PPPs are generally large capital intensive projects that attract the attention of taxpayers, and public dissatisfaction can cost governments their future votes. This can lead to government opportunism which can be dangerous for the agent and for the project itself. For example, the government may not support flexibility on pricing prior to election, even when the prices are set below cost recovery levels.

Moreover, it needs to be noted that mainstream PAT focus on the moral hazard problem, however, as De Palma et al. [13] highlights, one of the drawbacks of PAT is that it ignores the opportunism of the principal. Shrestha et al. [31] proposed the idea of a balanced risk allocation model in a principal agent environment where both the government and the concessionaire aim at attaining their own goals to increase their respective utility level (Figure 1). Undertaking risk responsibilities in a balanced manner can create a successful partnership for both the parties involved [31,50,51]. However, where there is an information advantage for one party, it may attempt to increase its utility at the expense of its partner. When this occurs, the balance is disrupted and likelihood of achieving project success is diminished [13]. Thus, PPP contracts should be designed and negotiated to encourage both parties to achieve a win-win balance through the efficient allocation of risks and responsibilities [31].

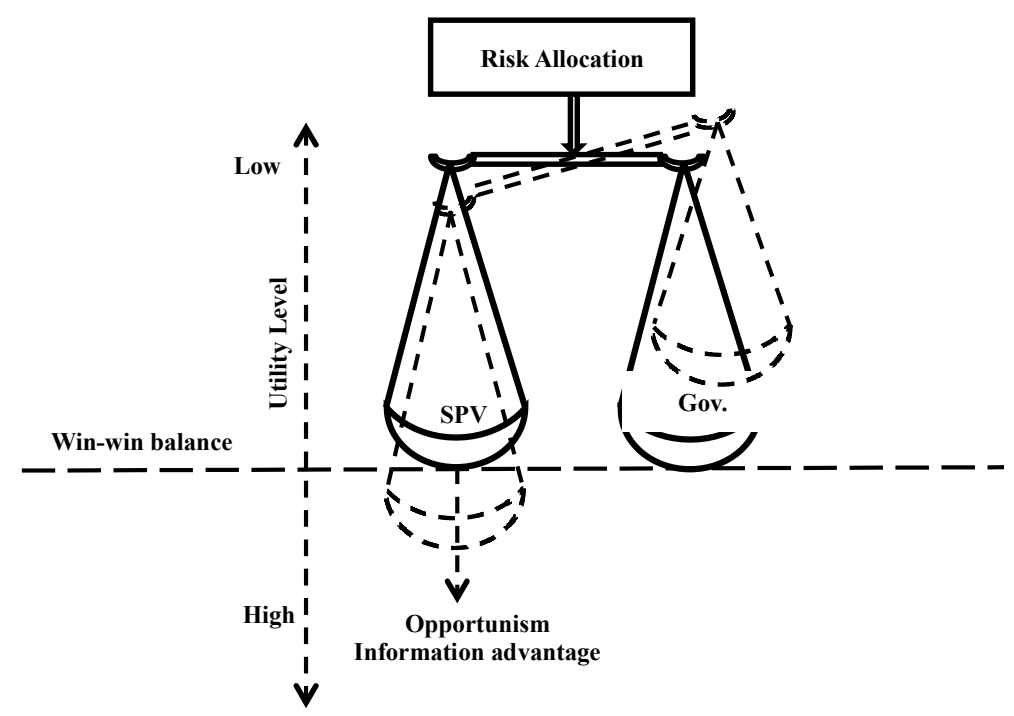

Figure 1. Role of risk allocation to achieve win- win balance [31]. Note: SPV: Special purpose vehicle; Gov: Government.

Therefore, the risk allocation framework presented herein aims to realize this by focusing upon the win-win risk allocation balance between the government and the private sector. Moreover, according to Zhang et al. [52], the correct approach to develop such frameworks requires a study grounded in the "very fundamental and time-honored theories" that it relates to. As a result, this research explores the core concepts of risk allocation principles through the theoretical lens of PAT.

\section{Research Method}

This study's defined objective is pursued through explanation building, by conducting a comprehensive literature review in accordance with the typology of review studies proposed by Paré et al. [53]. Such reviews seeks to make a contribution to the world of practice, by providing prescriptive guidelines to industry and practitioners. The aim of the review is to draw upon existing studies to identify, describe, and find application of principles in a real-world context [53]. Literature reviews add value to the body of knowledge of topics not fully developed as PPP risk 
allocation, since the process of synthesizing existing disparate information into comprehensive relationships allows for the development of prescriptive framework building with applicability to real-world situations [54].

A literature review was undertaken on the risks in PPP projects. Companion publications in the field were examined to the point of saturation, using a 'snowballing literature search' [55]. This resulted in the identification of 83 relevant published studies. Journals proved to be the richest source on PPP risk allocations, with the International Journal of Project Management; Journal of Construction Engineering \& Management; Journal of Infrastructure Systems; Journal of Engineering Construction \& Architectural management; Journal of Construction Management \& Economics; Utilities Policy; and Sustainability offering the largest collections. Books, book chapters, and technical reports on risk allocation, risk uncertainty, and the theory of incentives, were also retrieved. While structured review studies aim at providing a snapshot picture of the current state of a topic, theoretical review studies must draw on a wider range of published literature in order to capture the fullness of the debate [55], and this was the approach taken here.

Contribution of a study in construction management discipline can be assessed within its originality in development of knowledge, as well as, its impacts on practice [56,57]. In view of these two primary criteria, the contribution of the present study to the field is considered to be justified, for the most part, in terms of its implications for practice. Moreover, integrating the literature explores solutions to a real problem. The best types of studies that integrate the literature are those that add value to new thinking, and have relevance to the change of real-life behaviors to address a real need in the field. The contribution of the prescriptive framework presented here is therefore justified given that it presents new relationships, processes, and perspectives that have not been fully explored, a point argued by Torraco [58].

\section{Defining the Parameters of Risk Allocation}

There are several steps involved in the PPP risk allocation process. Initially, it is the private sector that assesses and prices project risks, with this pricing reflected in the tender bid to government.

In evaluating received bids, government will consider whether any of the identified risks can be transferred, and at what price. Ultimately, risks (and the compensation for bearing those risks), will typically be negotiated between parties, with a final agreement put in place on how the various project risks will be shared. According to the literature, in this regard, two main criteria prevail:

- $\quad$ Risk should reside with the party best able to mitigate the risk; and

- Risk should be transferred to the party who prices the risk at the lowest cost [27,59-61].

This principle is one developed from the perspective of viewing risk in economic terms: the party able to reduce risk more cheaply will be willing to take less compensation for bearing that risk. Consequently, in PPP projects, the prevailing wisdom is that the party to the agreement with the greatest capacity to reduce the likelihood of a risk eventuating, and to deal with it best should it eventuate, is the party to whom the risk should be allocated. Being the best able to mitigate a risk, in economic terms, equates with being able to mitigate that risk, and/or manage the consequences, at the lowest relative cost $[27,61]$.

In defining principles of risk allocation in construction projects, Max Abrahamson [62] defines five criteria; commonly known as the Abrahamson's principles. Abrahamson recommends the assignation of risk to a particular party where:

- It is in their control;

- It can be transferred as an economic transaction;

- The transfer accrues an economic benefit;

- Doing so creates greater overall efficiency; and

- Should the risk eventuate, the consequences do indeed fall on the party owning the risk. 
Extending this thesis, Arrow [63] analyzed risk allocation from a market transaction perspective, concluding that information as to the nature of a risk influences attitudes of both the buyer and seller with regard to the willingness to accept risk. Posner and Rosenfield [64] went on to establish the proposed identification of the preferred risk bearer to a contract: "(The) superior risk bearer is to be understood here as the party that is the more efficient bearer of the particular risk in question, in the particular circumstances of the transaction." [64]. They define the superior risk bearer as possessing greater ability in terms of:

- Minimizing the risk probability;

- Minimizing the degree of loss suffered, either before or after the risk event occurs; and

- Insuring against any residual risk that cannot be feasibly avoided.

In short, efficient risk allocation, as posited by the literature, identifies three parameters:

- Control;

- Information; and

- Incentives; discussed below, from the perspective of PAT in relation to PPPs.

\subsection{Parameter 1: Control}

In accordance with Abrahamson's principles [62] and the superior risk bearer theory [64], the party bearing any risk should also be in control of that risk, having sufficient ability to reduce both the probability and severity of the risk. Indeed, control is a well-established criterion in PPP risk allocation [10,12,21], and encompasses the ability to efficiently mitigate risk through outright prevention or through negative impact reduction, should the risk manifest [61].

However, in accordance with PAT, the principal must also ensure that the transferred risks are efficiently neutralized by the agent. Thus, the bid evaluation process, amongst the usual considerations, must also establish the capacity of the agent to control risks [31]. This capacity can be gauged by government during the tendering process by asking potential agents to include information in their bid on the costs for project delivery, cash flow and profit forecast, and the price for taking on risks [65]. Specifically, risk costings will be reflected in the bid price, and signal to the principal risk mitigation capabilities and the capacity to augment projected VfM [17].

Once the agent is nominated, the control parameter should be carefully assessed with regard to the allocation of risks between the principal and the agent. If at this stage the risks are not efficiently allocated, the moral hazard problem at the ex-post stages can be expected [19].

\subsection{Parameter 2: Information}

De Palma et al. [13] developed a risk allocation system for PPPs, using a principal agent based typology, proposing that risk allocation should be based on the level of information that companies and the government have available to them regarding risk. Triantis [66] reiterates that information is an essential consideration when allocating risks in contracts. These insights, together with Posner and Rosenfield's theory [64] of the superior risk bearer, reveal that the superior risk bearer is indeed the party with the superior information on the risks; specifically, with regard to assessment of risk probability, severity, as well as efficient allocation and mitigation.

Obtaining accurate risk related information aids in the evaluation of risks during the assessment stage. The party with inadequate information, or misinformation, will be at a disadvantage in regards to the value they place on a risk, which will result in an inadequate project bid. This type of error is known as internal uncertainty [67]. Similarly, a party's ability to control risks is contingent on their ability to acquire accurate risk-related information, and then to use it to assess risks [66].

Information asymmetry at ex ante stages leads to the adverse selection problem. Moreover, the lack of information or the inability to understand it complicates the rational risk assessment $[13,68-70]$. One of the risk management guidelines in ISO 31000 [71] clearly highlights that the management of risks 
should explicitly consider any limitations of unavailable information for a party to take responsibility of the risk.

At the ex-post stages, lack of information on project operations and performance leads to moral hazard [17]; to be more specific, the private sector can easily conceal their opportunistic actions in the presence of asymmetric information [72]. So, an aspect of monitoring that favors PPPs is the ease of measuring the performance via output standards [73], though standards put in place need to be clearly defined, measurable in quantitative and qualitative terms, and verifiable by third parties like courts or arbitrators [33]. The easier it is to measure performance, the lower the risk of the agent avoiding their responsibilities [45], and stronger the incentive for the private sector to perform [17].

\subsection{Parameter 3: Incentives}

Laffont and Vickrey [74] define 'incentives' as "the design of rules and institutions for inducing economic agents to exert a high level of effort (in the broad sense), and to reveal truthfully all socially relevant information they might have." Abrahamson's principles assert that the incentives to manage risks ought to be a criterion driving the allocation of risks. Similarly, Iossa et al. [33] point out that the primary objective of risk allocation is to provide incentives to both the private sector and government, to manage risks. Hölmstrom [75] also analyses risk sharing, arguing that the principal must expose the agent to some levels of risk in order to motivate them. It is the mechanism of incentives that prod agents into effective risk mitigation [76-78].

\section{The Risk Allocation Framework}

Figure 2 presents the developed framework, using a step-by-step process. It reveals the rationale for determining efficient risk allocation. The framework guides the process of risk assignation to one of either parties, or to a sharing of risk between parties. The outcome is an efficient allocation of project risk [52]. 


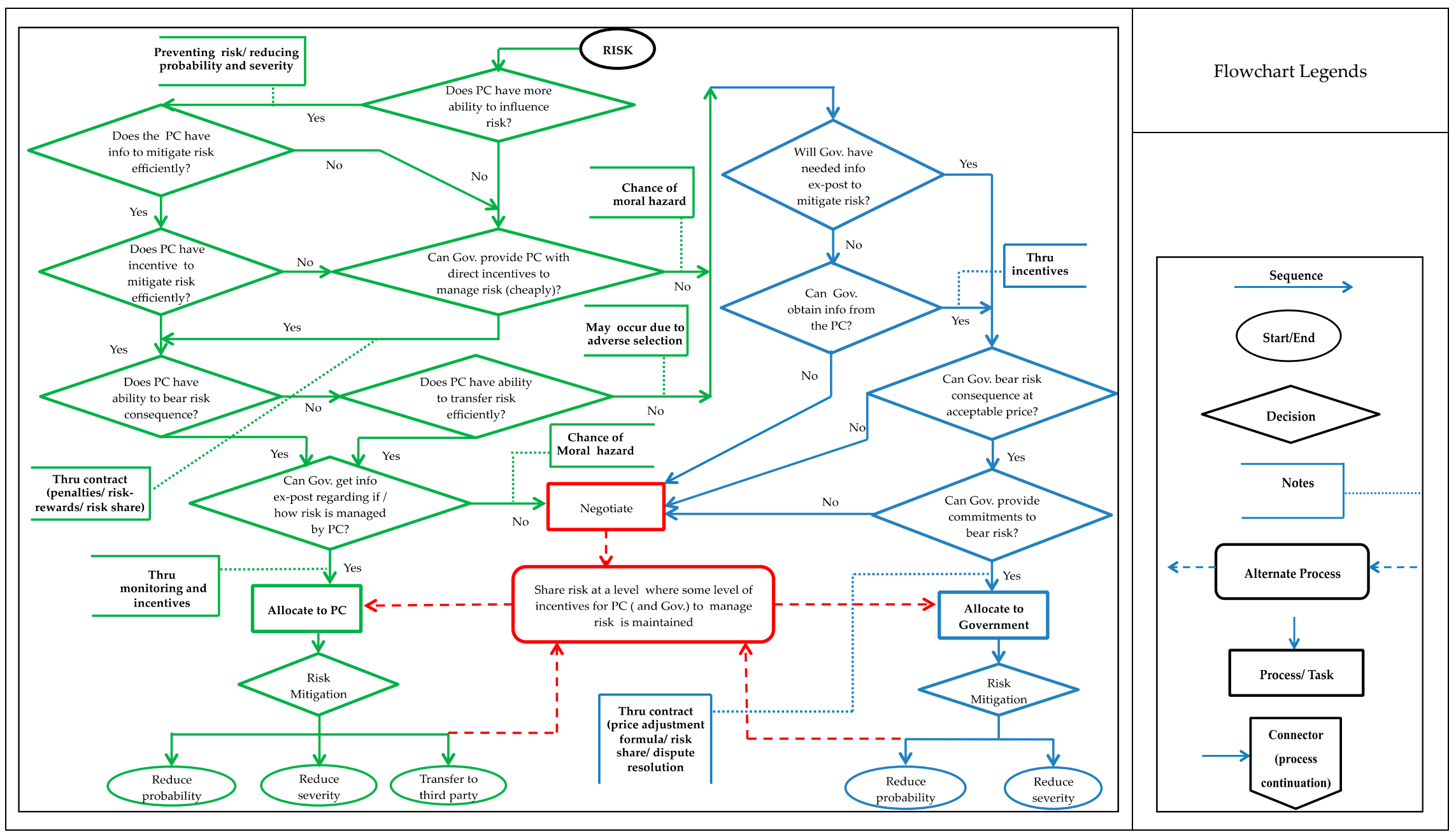

Figure 2. The risk allocation framework. Note: PC: Project Company; Gov: Government; Info: Information. 


\subsection{Project Company's Ability to Influence risks}

Step 1 of the framework establishes the criteria determining whether the private sector has the ability to influence the level of risk. The party that has the ability to influence a risk will also be in a position to prevent, or minimize, the negative impacts of that risk [21,79]. Controlling the risk before it manifests is consistent with the ability of the party to reduce the probability and severity of the risk. This applies particularly to endogenous risks. With such risks, the risk bearing party can instigate preventative measures before the risk materializes, eliminating the risk entirely, or at least reducing probability of occurrence [33]. Essential to the assessment, however, is an audit of the risk bearer's ability to take actions effective at reducing the risk impact. Reducing the impact applies for both exogenous risks and endogenous risks. This can be done via proper risk management planning, and by having back-up plans or contingency plans. For example, exogenous risks such as inflation may require mitigation measures that may include indexing revenues to inflation, fixed price contracting, etc.; such strategies reduce the potential impacts [27].

\subsection{Project Company's Information Regarding Risks}

Step 2 of the framework highlights information. For a party to comprehend the risks and to put together an effective risk management plan, information is needed. Estimating the likelihood of risks, and predicting the damage they can cause, is critical to effective risk management. Information will also bear on a party's ability to control risks [66]. Consequently, an assessment is needed to confirm that the private sector does have the necessary information. Here, information sharing between parties is needed, and the government, as custodians of the project, will have information pertinent to the private party $[13,33]$. Though the private sector superiority in regards to having endogenous risk information is taken as a given, the government may in fact be more informed on some endogenous risks such as regulatory changes, processes and permits and land acquisition. Moreover, better information on the project may be provided to potential bidders prior to tendering to facilitate in a better risk assessment [17].

\subsection{Incentives for Project Company to Manage Risks}

Steps 3 and 4 of the framework set out the criteria for incentives. This should be an important criterion to assess risk allocation. Risks should only be allocated to the private sector if they have the incentives to manage them. Thus, Step 3 determines if the private sector has (and will continue to have) the incentive to manage project risk, and Step 4 assesses if the government can provide the private sector with incentives to manage risk.

PPPs include an inherent mechanism to provide the private sector with the incentive to perform as their performance is interrelated with their financial return accrued [23], which incentivizes the private sector to control risks more efficiently. However, when there is a lack of ex-post competition and where the service fees are remunerated by the governments, there are fewer incentives for the private sector to perform, which then may lead to the moral hazard problem [17]. To prevent moral hazard occurring, incentives can be provided (or in some cases, imposed) to the private sector by the government. Incentives could either be negative incentives or positive incentives.

Providing the private sector with the right incentives can motivate them, but a key issue that needs to be examined yet again is whether the risk transfer using incentives is cheaper for governments compared to the costs of bearing the risks themselves. For endogenous risks, incentives can be more easily designed. For example, Shrestha et al. [17] demonstrated the use of incentives to transfer project related risks such as output/service standards via penalties for non-performance and delays; requirement of performance guarantees and bonds; and compulsory insurance to be taken up by the private sector, etc. Additionally, explicit performance standards in the contracts help reduce transaction costs. However, when risks are exogenous, then transferring risks via incentives will lead to an excessive risk premium [33]. So here, the only reason to transfer risk (or share it) is to this motivate the 
agent to increase the expected value of the project through increased effort. Governments also provide positive incentives to increase competition. When high-powered incentives to bear certain risks brings about an efficient risk mitigation, particularly when monitoring is difficult (or costly), then these risks can be transferred. However, if the private sector does not have the incentives to manage the risks and if/when the government cannot design the right incentives for the private sector to manage these risks, then there is strong chance that moral hazard will occur when the risks are transferred. It is therefore more efficient for the risks to be allocated to the government or shared between the two parties. Moreover, there is strong indication in literature that support the use of real options as a viable approach for predetermined risk sharing mechanisms which allows the parties to anticipate their costs of bearing (sharing) the risks [80] while creating opportunities that risks create at the ex post stages by incorporating renegotiations clauses [81].

\subsection{Project Company's Ability to Bear the Consequence of Risks}

Step 5 of the framework considers control and focuses on the private sector's ability to bear the consequences of the risk. When the private sector cannot bear the consequence of risks, the project will most likely suffer and the risks re-transferred back to the government. This may be particularly true for exogenous risks, where the ability to directly influence them is minimal and control depends upon the private sector's capability to endure the impacts of the risks without going insolvent. Failures in larger scale PPP projects generate social risks; therefore, governments must select a private company that is well equipped to control risks that occur. This is an important measure to mitigate the adverse selection problem. Good tendering practices along with strong and transparent competition allows better information signaling from bidders that determine the capability of the potential agents to manage risks $[17,23,82]$. Project companies can spread the cost of exogenous risk among a number of shareholders and/or among a diverse portfolio of projects [83].

\subsection{Project Company's Ability to Transfer Risks}

Step 6 once again investigates control by establishing criteria regarding the private sector's ability to transfer risks to third parties; such criteria is inextricably linked to Abrahamson's principle and Posner and Rosenfield's superior risk bearer theory. Hence, when it is known that the private sector cannot bear the consequences of a certain risk, then an evaluation is necessary to determine whether the private sector can transfer these risks to third parties. Many of the endogenous risks are transferred to third party entities by the project company via closed contracts with contractors and operators for construction and operation risks [27]. Some exogenous risk are transferred to third party insurances. For the private sector, transferring both exogenous and endogenous risks to third parties is an important risk mitigation measure and their ability to do so is based upon their project experience along with the familiarity and understanding of risks. Again, ex-ante competition may be important in ascertaining this ability of the private sector.

\subsection{Government's Ability to Acquire Ex-post Information}

Step 7 concerns the government's ability to acquire information regarding how/if the private sector efficiently manages the risks assigned to them at the project's ex-post stages. This step is important because it focuses on reducing information asymmetry. Even when all the previous criteria are met, the government must secure evidence on how the risks are being managed (or if managed at all). Failure to do so will mean that assigning risks to the private sector will not result in efficient risk allocation.

Monitoring the private sector's performance is essential to ensuring that the risk remains transferred. It not only reduces information asymmetry, but output specific monitoring also sets up incentives for the private sector to provide information to the government which can be important in transferring risks at the ex-post stages. 


\subsection{Risk Mitigation by Project Company}

Step 8 concerns risk mitigation by the private sector. The framework focuses on how the private sector mitigates risks allocated to it. At this stage, it is determined that the private sector is the superior risk bearer and based on the superior risk bearer theory, the private sector can mitigate risks efficiently either by reducing the probability/severity of the risks or by transferring risk to third parties. The most suitable way to mitigate risks can vary depending on the project situation and the private sectors' preference regarding which technique to employ. Selecting the most appropriate risk mitigation involves balancing the costs and efforts of implementation against the benefits derived [71]. Governments can however, require the private sector to mitigate (some) risks in a pre-determined manner as an incentive provision strategy [17]. This may be done via third party transfer such as mandatory insurance on certain risk items, or risk reduction by having systems in place allowing governments to sign off on decisions (such as selecting third party contractors).

\subsection{Government's Information on Risks and Agency Problems}

If the previous criteria in Steps 4, 6 and 7 to transfer risk are not satisfied, the government must consider bearing these risks themselves (and assess their ability to control the risks) to achieve an efficient outcome. Thus, the framework is developed further by setting out criteria to assist in the government's decision making process. Steps 9 and 10 of the framework assesses if the government possesses or can acquire the information needed to manage the risks. Governments are more likely to be less informed on risks compared to private sector companies. Possessing information in regards to the risks materializing is an important criterion for governments to be able to bear risks. Moreover, risks are interrelated and the occurrence of one risk can lead to the other [6], so understanding these risk relationships is equally important. Without information, the government may end up bearing risks which they cannot control, and with this their credibility is diminished and transferring risk to the private sector becomes more expensive-a so called 'social risk'.

\subsection{Government's Ability to Bear Risks}

Step 11 determines whether the government can bear the consequences of the risks if they occur. While the private sector may be better suited to manage endogenous risks [27], it is generally argued that the government has more control over exogenous risks [38]. However, governments bearing sole responsibility to manage all exogenous risks can prove very costly and diminish the benefits of PPPs. Furthermore, when governments take on some risks, it may turn out to be inefficient resulting from their lack of risk management skills. The government needs to avoid costly errors to limit social risks [31]. When both parties have insufficient capacity to influence the risk (mostly in the case of exogenous risks), the best option is to share the risk [38,79]. Hence, risks must be negotiated and shared through a risk sharing mechanism between the two parties.

\subsection{Government's Commitment to Bear Risks}

Step 12 of the framework sets the criteria regarding government's commitment to bear the risk. Government's credibility in managing their share of risks is often questioned and perceived as a major issue for private sectors involved in PPPs $[14,84,85]$. Often, major disputes or renegotiations may occur as a result of government's failure to commit, subsequently leading to higher transaction costs. It is therefore quintessentially important that governments commit to assume responsibility and keep promises made in the contract by bearing the risks that are allocated to them. As government opportunism is not uncommon in PPPs, the contract should ensure government commitment through clear price adjustment formulas, clear mechanisms for risk sharing, and reliable dispute resolution systems [17], and in some cases, call and put options [86]. These provide positive incentives to the private sector. These incentives also add to the government's credibility and reduce uncertainties from exogenous risks. 


\subsection{Sharing the Risk}

Finally, Step 13 considers risk sharing between the two parties-which can be in equal proportions or at varying proportions depending on the risk condition and how the contract is designed. Though, deciding on risk sharing mechanisms may again involve negotiations resulting in unresolved allocation. Notably, if the private sector has been already selected when this framework is applied, then, a shift in the bargaining power between the parties may have occurred. Due to the absence of (further) competition, there is less incentive for the private sector to take on risks. Consequently, a moral hazard problem leading to a hold-up may occur [87]. Whilst conversely, the government may not find it necessary to provide any positive incentives, since they do not have the pressure of selling the project when the private sector is already selected. In this case, opportunism on the part of the government may occur which can lead to inefficient risk transfer and subsequently, higher transaction cost. Therefore, it might be necessary at this stage to allocate risks on the basis of the information (in regards to efficient risk allocation) assessed during the previous steps of the framework.

Risks can be shared using various mechanisms depending on the nature of the risks, the market conditions, as well as the principal agent environment in which there the negotiation takes place. For risks that are affected by exogenous factors, the risk sharing mechanism may involve revenue guarantees, interest rate guarantees, guarantees on force majeure events, and in some cases, guarantees on the demand for services. These guarantees can take the form of reimbursements, subsidies, price adjustments, extension of concession period, or termination arrangements. Real options approach can often be found in these risk sharing mechanisms to incorporate the flexibilities [86]. However, when the guarantees are not set well, they can create serious issues, specifically for the governments [88]. There have been several studies that calculate the optimal levels of predefined guarantees-revenue guarantees [88], interest rate guarantees [80], and the determination of the concession period [51]. However, it is critical for the governments to have accurate information to use these models; this brings us back to the government information parameter in steps 9 and 10 of the risk allocation framework.

On a different note, risks sharing may also be designed based on relational contracts where both parties can jointly manage risks rather than allocating them to one party [89]. An alliance agreement can be made between the government and private sector companies in good faith, where both commit to work cooperatively, sharing the project's risk and rewards in order to achieve the stated outcomes. In addition, government can provide incentives via pain share-gain share mechanisms, where both the costs and rewards of the risks can be shared between the two parties.

\section{Conclusions}

This study offers two main contributions to the management of risk in PPP projects. First, existing risk frameworks aim to identify risks, and then only to recommend how those risks should be allocated. The framework proposed here extends this objective through a deeper understanding of risk afforded by PAT, to ensure those risks are more completely identified and then optimally allocated across the whole of the PPP project lifecycle.

Secondly, in theoretical terms, this study merges standard risk allocation theory with PAT. In so doing, it extends both the understanding of project risk by incorporating social dynamic factors with probabilistic uncertainty, while providing a guided approach to determining where and with whom those risks should be assigned. Specifically, this framework provides a rational mechanism for determining whether any specific risk should be borne by the private or governmental partner in the project, or shared.

There are clear implications from the framework, both initially during risk allocation negotiations and subsequently, during operations. That is, the framework provides a guiding tool at each step of the project, allowing both the government and private sector to access the equitability of allocating risks a certain way. At the ex-post stages, the framework can be applied periodically to determine if risk allocations remain equitable. The application of the framework is particularly salient where the nature 
of the risks change over time and re-negotiation of risk allocation are called for. Indeed, the framework itself presents a mechanism by which such risk reviews and renegotiations may be facilitated.

The practical benefit of allocating risks more efficiently is self-evident. On the project side, firstly, the probability of risks materializing can be expected to reduce. Moreover, should risks eventuate, they can be more effectively managed and their negative impacts contained. These benefits can be expected to translate into cost-reductions and performance improvements over the life of the project. Secondly, for the stakeholders-the government and the private sector-improved risk allocation facilitates smoother cooperation between interested parties, and reduced conflicts of interest between those parties and that of the project itself.

One of the limitations of this study is the use of a rather defensive approach that focuses on the downside of risks. Risks can have a positive or a negative impact on the project. However, this study generally focused on the negative aspects of risks to solve the issues related principal agent relationship. Future research may further this framework by incorporating risk mitigation parameters that facilitate in enhancing positive risks or in the sharing of risks.

Moreover, this framework is the result of the integration of numerous studies in the field, and as such, while rigorous in its comprehensive inclusion of known parameters affecting risk identification and allocation, has yet to be validated. Such validation is the necessary next step and should be carried out using a case study approach in a live PPP contextual setting. Additional lines of future research may include:

Future research directions may also include:

- Assessing stakeholder capacity to mitigate various risk categories;

- Determining triggers and events by which risks best borne by one particular party shift to be optimally borne by another;

- Extending the pricing of risk to incorporate the pricing of risk information asymmetry;

- Exploration of PPP contract development that recognizes PAT and its impact on risk allocation, with the view to limiting the opportunities and incentives to extract advantage by any one party at the expense of exacerbating project risk factors, while also optimizing risk allocations between contracting parties.

Author Contributions: Conceptualization, A.S. and M.R.H.; methodology, D.J.E.; validation J.T.; formal analysis, A.S. and I.M.; resources, I.M.; data curation, A.S. and I.M.; writing-original draft preparation, A.S. and J.T.; writing - review and editing, J.T.; visualization, I.M. and M.R.H.

Funding: This research received no external funding.

Conflicts of Interest: The authors declare no conflict of interest.

\section{References}

1. Berezin, A.; Sergi, B.; Gorodnova, N. Efficiency Assessment of Public-Private Partnership (PPP) Projects: The Case of Russia. Sustainability 2018, 10, 3713. [CrossRef]

2. Heathcote, C. Forecasting Infrastructure Investment Needs for 50 Countries, 7 Sectors through 2040. Global Infrastructure Outlook and Oxford Economics. 2017. Available online: https://blogs.worldbank. $\mathrm{org} / \mathrm{ppps} /$ forecasting-infrastructure-investment-needs-50-countries-7-sectors-through-2040 (accessed on 8 November 2019).

3. Yu, Y.; Chan, A.P.C.; Chen, C.; Darko, A. Critical risk factors of transnational public private partnership projects: Literature review. J. Infrastruct. Syst. 2018, 24, 04017042. [CrossRef]

4. Cheng, Z.; Ke, Y.; Lin, J.; Yang, Z.; Cai, J. Spatio-temporal dynamics of public private partnership projects in China. Int. J. Proj. Manag. 2016, 34, 1242-1251. [CrossRef]

5. Feng, K.; Xiong, W.; Wang, S.; Wu, C.; Xue, Y. Optimizing an Equity Capital Structure Model for Public Private Partnership Projects Involved with Public Funds. J. Constr. Eng. Manag. 2017, 143, 04017067. [CrossRef]

6. Shrestha, A.; Chan, T.-K.; Aibinu, A.A.; Chen, C.; Martek, I. Risks in PPP water projects in China: Perspective of local governments. J. Constr. Eng. Manag. 2017, 143, 05017006. [CrossRef] 
7. Grimsey, D.; Lewis, M.K. Evaluating the risks of public private partnerships for infrastructure projects. Int. J. Proj. Manag. 2002, 20, 107-118. [CrossRef]

8. Hwang, B.-G.; Zhao, X.; Gay, M.J.S. Public private partnership projects in Singapore: Factors, critical risks and preferred risk allocation from the perspective of contractors. Int. J. Proj. Manag. 2013, 31, 424-433. [CrossRef]

9. Xiong, W.; Zhao, X.; Yuan, J.-F.; Luo, S. Ex post risk management in public-private partnership infrastructure projects. Proj. Manag. J. 2017, 48, 76-89. [CrossRef]

10. Ke, Y.; Wang, S.; Chan, A. Risk Allocation in Public-Private Partnership Infrastructure Projects: Comparative Study. J. Infrastruct. Syst. 2010, 16, 343-351. [CrossRef]

11. Wang, H.; Xiong, W.; Wu, G.; Zhu, D. Public-private partnership in public administration discipline: A literature review. Public Manag. Rev. 2017, 20,1-24. [CrossRef]

12. Shrestha, A.; Chan, T.K.; Aibinu, A.A.; Chen, C.; Martek, I. Risk allocation inefficiencies in Chinese PPP water projects. J. Constr. Eng. Manag. 2018, 144, 04018013. [CrossRef]

13. De Palma, A.; Leruth, L.E.; Prunier, G. Towards a Principal-Agent Based Typology of Risks in Public-Private Partnerships. Reflets Perspect. Économique 2012, 51, 57-73. [CrossRef]

14. Shrestha, A.; Martek, I. Principal agent problems evident in Chinese PPP infrastructure projects. In Proceedings of the 19th International Symposium on Advancement of Construction Management and Real Estate; Mao, C., Shen, Y.L., Ye, K.H., Eds.; Springer: Berlin, Germany, 2015; pp. 759-770.

15. Flyvbjerg, B.; Garbuio, M.; Lovallo, D. Delusion and Deception in Large Infrastructure Projects: Two Models for Explaining and Preventing Executive Disaster. Calif. Manag. Rev. 2009, 51, 170-194. [CrossRef]

16. Wang, Y.; Liu, J. Evaluation of the excess revenue sharing ratio in PPP projects using principal-agent models. Int. J. Proj. Manag. 2015, 33, 1317-1324. [CrossRef]

17. Shrestha, A.; Chan, T.-K.; Aibinu, A.A.; Chen, C. Efficient risk transfer in PPP wastewater treatment projects. Util. Policy 2017, 48, 132-140. [CrossRef]

18. Valipour, A.; Sarvari, H.; Tamošaitienè, J. Risk assessment in PPP projects by applying different MCDM methods and comparative results analysis. Adm. Sci. 2018, 8, 80. [CrossRef]

19. Mu, R.; de Jong, M.; ten Heuvelhof, E. A typology of strategic behaviour in PPPs for expressways: Lessons from China and implications for Europe. Eur. J. Transp. Infrastruct. Res. 2010, 1, 42-62.

20. Hatefi, S.M.; Tamošaitienè, J. An integrated fuzzy DEMATEL-fuzzy ANP model for evaluating construction projects by considering interrelationships among risk factors. J. Civ. Eng. Manag. 2019, 25, 114-131. [CrossRef]

21. Lam, K.C.; Wang, D.; Lee, P.T.K.; Tsang, Y.T. Modelling risk allocation decision in construction contracts. Int. J. Proj. Manag. 2007, 25, 485-493. [CrossRef]

22. Jin, X.; Zhang, G. Modelling optimal risk allocation in PPP projects using artificial neural networks. Int. J. Proj. Manag. 2011, 29, 591-603. [CrossRef]

23. Mota, J.; Moreira, A.C. The importance of non-financial determinants on public-private partnerships in Europe. Int. J. Proj. Manag. 2015, 33, 1563-1575. [CrossRef]

24. Kwak, Y.H.; Chih, Y.; Ibbs, C.W. Towards a comprehensive understanding of public private partnerships for infrastructure development. Calif. Manag. Rev. 2009, 51, 51-78. [CrossRef]

25. Mot MacDonald International Ltd. Review of Large Public Procurement in the UK; Mot MacDonald International Ltd.: Croydon, UK, 2002. Available online: https://www.parliament.vic.gov.au/images/stories/committees/ paec/2010-11_Budget_Estimates/Extra_bits/Mott_McDonald_Flyvberg_Blake_Dawson_Waldron_studies. pdf (accessed on 1 July 2018).

26. Raisbeck, P.; Duffield, C.; Xu, M. Comparative performance of PPPs and traditional procurement in Australia. Constr. Manag. Econ. 2010, 28, 345-359. [CrossRef]

27. Marques, R.C.; Berg, S. Risks, contracts, and private-sector participation in infrastructure. J. Constr. Eng. Manag. 2011, 137, 925-932. [CrossRef]

28. Wu, Y.; Li, L.; Xu, R.; Chen, K.; Hu, Y.; Lin, X. Risk assessment in straw-based power generation public-private partnership projects in China: A fuzzy synthetic evaluation analysis. J. Clean. Prod. 2017, 161, 977-990. [CrossRef]

29. Li, B.; Akintoye, A. An overview of public-private partnership. In Public-Private Partnerships: Managing Risks and Opportunities; Akintoye, A., Beck, M., Hardcastle, C., Eds.; Blackwell Science: Malden, MA, USA, 2008. 
30. Ng, S.T.; Wong, Y.M.; Wong, J.M. Factors influencing the success of PPP at feasibility stage-A tripartite comparison study in Hong Kong. Habitat Int. 2012, 36, 423-432. [CrossRef]

31. Shrestha, A.; Aibinu, A.A.; Chan, T.K.; Chen, C. Risk allocation in public private partnerships in China's water projects: A principal agent approach. In Water Resources Management; Brebbia, C.A., Ed.; WIT Press: South Hampton, NH, USA, 2013; Volume 171, pp. 85-96.

32. Chen, C.; Hubbard, M. Power relations and risk allocation in the governance of public private partnerships: A case study from China. Policy Soc. 2012, 31, 39-49. [CrossRef]

33. Iossa, E.; Spagnolo, G.; Vellez, M. Contract Design in Public-Private Partnerships. Ber. Weltbank 2007, $12,2010$.

34. Loosemore, M.; McCarthy, C. Perceptions of contractual risk allocation in construction supply chains. J. Prof. Issues Eng. Educ. Pract. 2008, 134, 95-105. [CrossRef]

35. Ameyaw, E.; Chan, A. A fuzzy approach for the allocation of risks in public-private partnership water-infrastructure projects in developing countries. J. Infrastruct. Syst. 2016, 22, 04016016. [CrossRef]

36. March, J.G.; Shapira, Z. Managerial perspectives on risk and risk taking. Manag. Sci. 1987, 33, 1404-1418. [CrossRef]

37. Bahli, B.; Rivard, S. The information technology outsourcing risk: A transaction cost and agency theory-based perspective. J. Inf. Technol. 2003, 18, 211-221. [CrossRef]

38. Li, B.; Akintoye, A.; Edwards, P.; Hardcastle, C. The allocation of risk in PPP/PFI construction projects in the UK. Int. J. Proj. Manag. 2005, 23, 25-35.

39. Jensen, M.C.; Meckling, W.H. Theory of the firm: Managerial behavior, agency costs and ownership structure. J. Financ. Econ. 1976, 3, 305-360. [CrossRef]

40. Liu, J.; Gao, R.; Cheah, C.Y.J.; Luo, J. Incentive mechanism for inhibiting investors' opportunistic behavior in PPP projects. Int. J. Proj. Manag. 2016, 34, 1102-1111. [CrossRef]

41. Coase, R.H. The nature of the firm. Economica 1937, 4, 386-405. [CrossRef]

42. Alchian, A.A.; Demsetz, H. The property right paradigm. J. Econ. Hist. 1973, 33, 16-27. [CrossRef]

43. Demsetz, H. Toward a theory of property rights II: The competition between private and collective ownership. J. Leg. Stud. 2002, 31, S653-S672. [CrossRef]

44. Picard, P. On the design of incentive schemes under moral hazard and adverse selection. J. Public Econ. 1987, 33, 305-331. [CrossRef]

45. Amagoh, F. Information asymmetry and the contracting out process. Innov. J. 2009, 14, 1-14.

46. Laffont, J.J.; Martimort, D. The Theory of Incentives: The Principal-Agent Model; Princeton University Press: Princeton, NJ, USA, 2002.

47. Smyth, H.; Edkins, A. Relationship management in the management of PFI/PPP projects in the UK. Int. J. Proj. Manag. 2007, 25, 232-240. [CrossRef]

48. English, L.; Baxter, J. The changing nature of contracting and trust in public-private partnerships: The case of Victorian PPP prisons. Abacus 2010, 46, 289-319. [CrossRef]

49. Buxbaum, J.N.; Ortiz, I.N. Public Sector Decision Making for Public-Private Partnerships; Transportation Research Board: Washington, DC, USA, 2009.

50. Valipour, A.; Yahaya, N.; Noor, N.M.D.; Valipour, I.; Tamošaitienè, J. A SWARA-COPRAS approach to the allocation of risk in water and sewerage public-private partnership projects in Malaysia. Int. J. Strateg. Prop. Manag. 2019, 23, 269-283. [CrossRef]

51. Carbonara, N.; Costantino, N.; Pellegrino, R. Concession period for PPPs: A win-win model for a fair risk sharing. Int. J. Proj. Manag. 2014, 32, 1223-1232. [CrossRef]

52. Zhang, S.; Gao, Y.; Feng, Z.; Sun, W. PPP application in infrastructure development in China: Institutional analysis and implications. Int. J. Proj. Manag. 2015, 33, 497-509. [CrossRef]

53. Paré, G.; Trudel, M.-C.; Jaana, M.; Kitsiou, S. Synthesizing information systems knowledge: A typology of literature reviews. Inf. Manag. 2015, 52, 183-199. [CrossRef]

54. Shields, P.M.; Tajalli, H. Intermediate Theory: The missing link in successful student scholarship. J. Public Aff. Educ. 2006, 12, 313-334. [CrossRef]

55. Ray, P.; Trisha, G.; Gill, H.; Kieran, W. Realist review-A new method of systematic review designed for complex policy interventions. J. Health Serv. Res. Policy 2005, 10, 21-34.

56. Azhar, S.; Ahmad, I.; Sein, M.K. Action research as a proactive research method for construction engineering and management. J. Constr. Eng. Manag. 2009, 136, 87-98. [CrossRef] 
57. Green, S.D.; Kao, C.C.; Larsen, G.D. Contextualist research: Iterating between methods while following an empirically grounded approach. J. Constr. Eng. Manag. 2009, 136, 117-126. [CrossRef]

58. Torraco, R.J. Writing integrative literature reviews: Guidelines and examples. Hum. Resour. Dev. Rev. 2005, 4, 356-367. [CrossRef]

59. Abdel Aziz, A.M. Successful Delivery of Public-Private Partnerships for Infrastructure Development. J. Constr. Eng. Manag. 2007, 133, 918-931. [CrossRef]

60. Shen, L.Y.; Platten, A.; Deng, X. Role of public private partnerships to manage risks in public sector projects in Hong Kong. Int. J. Proj. Manag. 2006, 24, 587-594. [CrossRef]

61. Rahman, M.M.; Kumaraswamy, M.M. Joint risk management through transactionally efficient relational contracting. Constr. Manag. Econ. 2002, 20,45-54. [CrossRef]

62. Abrahamson, M. Contractual risks in tunnelling: How they should be shared. Tunn. Tunn. 1973, 587-598.

63. Arrow, K.J. Risk Allocation and Information: Some Recent Theoretical Developments; Institute for Economic Research, Queen's University: Kingston, ON, Canada, 1978.

64. Posner, R.A.; Rosenfield, A.M. Impossibility and related doctrines in contract law: An economic analysis. J. Leg. Stud. 1977, 6, 83-118. [CrossRef]

65. Crampes, C.; Estache, A. Regulatory trade-offs in the design of concession contracts. Util. Policy 1998, 7, 1-13. [CrossRef]

66. Triantis, G.G. Contractual allocations of unknown risks: A critique of the doctrine of commercial impracticability. Univ. Tor. Law J. 1992, 42, 450-483. [CrossRef]

67. Kahneman, D.; Slovic, P.; Tversky, A. Judgment under Uncertainty: Heuristics and Biases; Cambridge University Press: Cambridge, UK, 1982.

68. Zavadskas, E.K.; Turskis, Z.; Tamošaitienè, J. Risk assessment of construction projects. J. Civ. Eng. Manag. 2010, 16, 33-46. [CrossRef]

69. Ghasemi, F.; Mohammad, H.M.S.; Yousefi, V.; Falsafi, R.; Tamošaitienè, J. Project portfolio risk identification and analysis, considering project risk interactions and using Bayesian networks. Sustainability 2018, 10, 1609. [CrossRef]

70. Chatterjee, K.; Zavadskas, E.K.; Tamošaitienè, J.; Adhikary, K.; Kar, S. A hybrid MCDM technique for risk management in construction projects. Symmetry 2018, 10, 46. [CrossRef]

71. International Organization for Standardization ISO 31000 Risk Management. 2018. Available online: https: //www.iso.org/iso-31000-risk-management.html (accessed on 1 September 2019).

72. Parker, D.W.; Dressel, U.; Chevers, D.; Zeppetella, L. Agency theory perspective on public-private-partnerships: International development project. Int. J. Product. Perform. Manag. 2018, 67, 239-259. [CrossRef]

73. Koontz, T.M.; Thomas, C.W. Measuring the performance of public-private partnerships: A systematic method for distinguishing outputs from outcomes. Public Perform. Manag. Rev. 2012, 35, 769-786. [CrossRef]

74. Laffont, J.-J. William Vickrey: A Pioneer in the Economics of Incentives, Nobel Prize Lectures 27 December. 1996. Available online: http://www.nobelprize.org/nobel_prizes/economics/laureates/1996/vickrey-lecture. html (accessed on 20 April 2016).

75. Hölmstrom, B. Moral hazard and observability. Bell J. Econ. 1979, 10, 74-91. [CrossRef]

76. Lefebvre, M.; Vieider, F.M.; Villeval, M.C. Incentive effects on risk attitude in small probability prospects. Econ. Lett. 2010, 109, 115-120. [CrossRef]

77. Ward, S.; Chapman, C.; Curtis, B. On the allocation of risk in construction projects. Int. J. Proj. Manag. 1991, 9, 140-147. [CrossRef]

78. Ahmed, S.M.; Ahmad, R.; Saram, D.; Darshi, D. Risk management trends in the Hong Kong construction industry: A comparison of contractors and owners perceptions. Eng. Constr. Archit. Manag. 1999, 6, 225-234. [CrossRef]

79. Ke, Y.; Wang, S.; Chan, A.P.C.; Lam, P.T.I. Preferred risk allocation in China's public-private partnership (PPP) projects. Int. J. Proj. Manag. 2010, 28, 482-492. [CrossRef]

80. Pellegrino, R.; Carbonara, N.; Costantino, N. Public guarantees for mitigating interest rate risk in PPP projects. Built Environ. Proj. Asset Manag. 2019, 9, 248-261. [CrossRef]

81. Krüger, N.A. To kill a real option-Incomplete contracts, real options and PPP. Transp. Res. Part A: Policy Pract. 2012, 46, 1359-1371. [CrossRef]

82. Jefferies, M.; Gameson, R.; Rowlinson, S. Critical success factors of the BOOT procurement system: Reflections from the Stadium Australia case study. Eng. Constr. Archit. Manag. 2002, 9, 352-361. [CrossRef] 
83. Klein, M.W. Bidding for Concessions; World Bank, Private Sector Development Department, Private Participation in Infrastructure Division: Washington, DC, USA, 1998.

84. Chan, A.P.C.; Yeung, J.F.Y.; Yu, C.C.P.; Wang, S.Q.; Ke, Y. Empirical Study of Risk Assessment and Allocation of Public-Private Partnership Projects in China. J. Manag. Eng. 2011, 27, 136-148. [CrossRef]

85. Chan, A.P.C.; Lam, P.; Wen, Y.; Ameyaw, E.; Wang, S.Q.; Ke, Y. Cross-Sectional Analysis of Critical Risk Factors for PPP Water Projects in China. J. Infrastruct. Syst. 2014, 21, 10. [CrossRef]

86. Almarri, K.; Blackwell, P. Improving risk sharing and investment appraisal for PPP procurement success in large green projects. Procedia Soc. Behav. Sci. 2014, 119, 847-856. [CrossRef]

87. Chang, C.-Y. Understanding the hold-up problem in the management of megaprojects: The case of the Channel Tunnel Rail Link project. Int. J. Proj. Manag. 2013, 31, 628-637. [CrossRef]

88. Carbonara, N.; Pellegrino, R. Revenue guarantee in public-private partnerships: A win-win model. Constr. Manag. Econ. 2018, 36, 584-598. [CrossRef]

89. Zou, W.; Kumaraswamy, M.; Chung, J.; Wong, J. Identifying the critical success factors for relationship management in PPP projects. Int. J. Proj. Manag. 2014, 32, 265-274. [CrossRef]

(C) 2019 by the authors. Licensee MDPI, Basel, Switzerland. This article is an open access article distributed under the terms and conditions of the Creative Commons Attribution (CC BY) license (http://creativecommons.org/licenses/by/4.0/). 